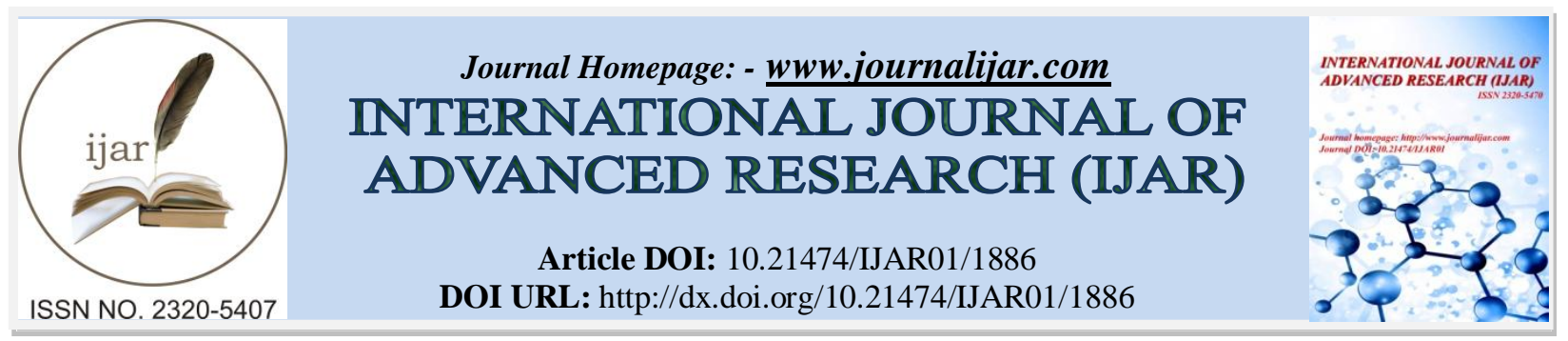

RESEARCH ARTICLE

\title{
BASEL II NORMS - OPPORTUNITIES and CHALLENGES FOR BANKS IN INDIA.
}

\section{Hemali Tanna.}

Ph.D Scholar, Management Department, Gujarat Technological University, Gujarat, India \& Assistant Professor, Marwadi Education Foundation's Group of Institutions, Rajkot, Gujarat, India.

\section{Manuscript Info}

Manuscript History

Received: 12 August 2016

Final Accepted: 22 September 2016

Published: October 2016

Key words:-

Basel II Norms, Opportunities,

Challenges, Banks in India

\section{Abstract}

Globalization has resulted in making world a small local economy. All the businesses have easy access to other players in the same industry in any part of the world. So it is very important to be competitive and maintain that sustainable advantage. The same logic holds true for banks across the world. The benefit is catering to customers abroad and sourcing funds from other countries, but banks are exposed to a variety of risks in global financial system. One such robust international regulatory framework is Basel norms, which promotes risk management mechanism and ensures financial stability. It is implemented by majority central banks of various countries. India too adopted Basel II framework in the year 2009. The present research paper highlights the significant features of Basel II Accord for the overall banking system. It discusses the impact of Basel II guidelines with reference to how it will change banking practices in India and what are the opportunities created post implementing Basel II norms. The study then focuses on mentioning some of the challenges faced by banks in India for adopting the regulations as mentioned in the Basel II Accord.

Copy Right, IJAR, 2016,. All rights reserved.

\section{Introduction:-}

Background of the study:-

The author has tried to understand the structure of Basel II framework and its important features to implement the same in banking operations. The present study aims to emphasize the important parameters of Basel II norms and analyses its impact on Banks in India. It mentions some of the opportunities generated from adopting Basel II norms. It also focuses on the challenges experienced while implementing Basel II framework in the Indian Banking Industry.

The objectives of the study:-

- To study the significant features of Basel II guidelines and understand its framework for implementation

- To understand how will Basel II Norms change banking in India

- To explore the opportunities for Indian banks post implementing Basel II framework

- To find out the changes adopted in the risk management system after practicing Basel II Accord

- To investigate the challenges experienced by banks in India while adopting Basel II framework in their operations 
- The paper is an endeavor to augment the knowledge of Basel II Norms to bankers, strategists, policy makers, academic researchers and other financial professionals.

\section{Methodology:-}

This paper is the outcome of secondary data collection and analysis of Basel II Norms and Indian banking sector collected from various appropriate sources. The article is sectioned into three parts. The first part includes the introduction, salient features of Basel II norms and its implementation in the Indian Banking Sector. The second part discusses the impact of Basel II framework, mentioning the opportunities generated for banks in India. Finally, the third part outlines some of the challenges experienced by banks in India while adopting the Basel II Accord.

\section{Introduction to Basel norms:-}

Banking Industry is the foundation on which growth of any economy can be constructed. The journey of Indian Banking Industry has passed through several stages of development. Even though banks at international level faced economic crisis of United States in 2008-09 and then followed by crisis in Europe. The common scenario of world financial system is very crucial. It is then that the role of regulatory organizations and framework comes to rescue. Banking rules and strict regulations prevents and helps face the crisis well in advance. (1)

One such strong regulatory institution is the Bank for International Settlements (BIS). The mission of BIS is to provide central banks with monetary and financial stability, to promote support and co-operation at international level and to act as a bank for central banks across the world. The head office of BIS is located in the city named Basel, Switzerland. (2)

The Basel Accords refer to the banking supervision Accords which are mainly recommendations on banking regulations. Basel Accords are issued by the Basel Committee on Banking Supervision (BCBS). They are known as Basel norms because BCBS has its secretariat at BIS which is located in Basel, Switzerland and the team of central banks usually meets there. (3)

\section{Objective of Basel Accords:-}

Basel Accord is a regulatory framework which focuses on mitigating risks faced by banks and financial institutions. The rationale of the accord is to make sure that banks have sufficient capital on hand to fulfill its expected obligations and absorb unforeseen losses. So far, Basel Accord has prescribed three Basel Norms which are familiarly known as Basel I, Basel II and Basel III Norms. (4)

\section{Basel I Accord:-}

The Basel Committee on Banking Supervision (BCBS) pioneered the first regulatory framework in the year 1988, which was known as capital measurement system or Basel Capital Accord. It was then familiarly known as Basel I. This accord focused completely on measuring and managing credit risk faced by banks. It also defined capital and structure of risk weights to be maintained by banks for its various categories of assets. The minimum capital requirement under this accord was fixed at $8 \%$ of Risk Weighted Assets (RWA) of banks. RWA means assets with different risk profiles. For example, an asset (loan) which is unsecured is more risky and will have higher risk weights compared to a secured and mortgage loan with appropriate collateral security, which will have lesser risk weights. India implemented Basel I framework in the year 1999. $(4,5)$

\section{Objective of Basel I Accord:-}

- To reinforce the financial stability of the international banking system

- To establish a reliable and robust banking system which will lead to decrease in competitive inequality of banks at international level (6)

\section{Merits \& Demerits of Basel I:-}

Basel I Accord was successful in raising the overall level of equity capital in the banking system. But it resulted in some unintentional consequences. Firstly, it does not categorize risks properly. It awkwardly encourages finding risks in assets of banks. (5)

\section{Basel II Accord:-}

Basel I framework focused on credit risk and regulatory capital requirement better than any other financial guidelines. But gradually, some loopholes were found in Basel I norms and then the Basel Committee introduced 
"International Convergence of Capital Measurement and Capital Standards: A Revised Framework", which was famously known as Basel II norms in the year June 2004. (6)

In the year 1999, the Committee came up with a proposal for a new capital adequacy framework to replace the previous Basel I Accord of 1988. This resulted in the launch of Revised Capital Framework in June 2004, which is popularly known as Basel II. Basel II Accord was popularly known as advanced and improved version of Basel I Accord. (5)

Details about Basel II Accord/ Pillars of Basel II framework:-

The Basel II rests on three pillars, Pillar I is Minimum Capital Requirements, Pillar II discusses Supervisory Review Process and Pillar III mentions about Market Discipline. (7)

The first pillar of Minimum Capital Requirement moves ahead of "one size fits all" approach of Basel I Accord. It is because Basel I focused only on credit risk, it completely ignored other risks faced by banks. Hence, Basel II framework considers measuring three types of risks namely credit risk, operational risk and market risk. The other benefit is Basel II guidelines provides choices and allows the banks to select any one approach of measuring risk, according to the needs and capacity of bank. The second pillar of Supervisory Review Process emphasizes on supervision of assessment and review of bank's risk management system by the top management of the respective banks. Internal and external auditors are appointed to administer the risk measurement and evaluation system of banks. The third pillar of Market Discipline highlights the importance of disclosure of significant information of banks to market participants. It includes disclosing particular variables of banks to financial markets, so as they can properly value and discipline them. The information disclosed by banks will be used by all its stakeholders. (8)

The three pillars of Basel II Accord can be easily understood from the following figure:

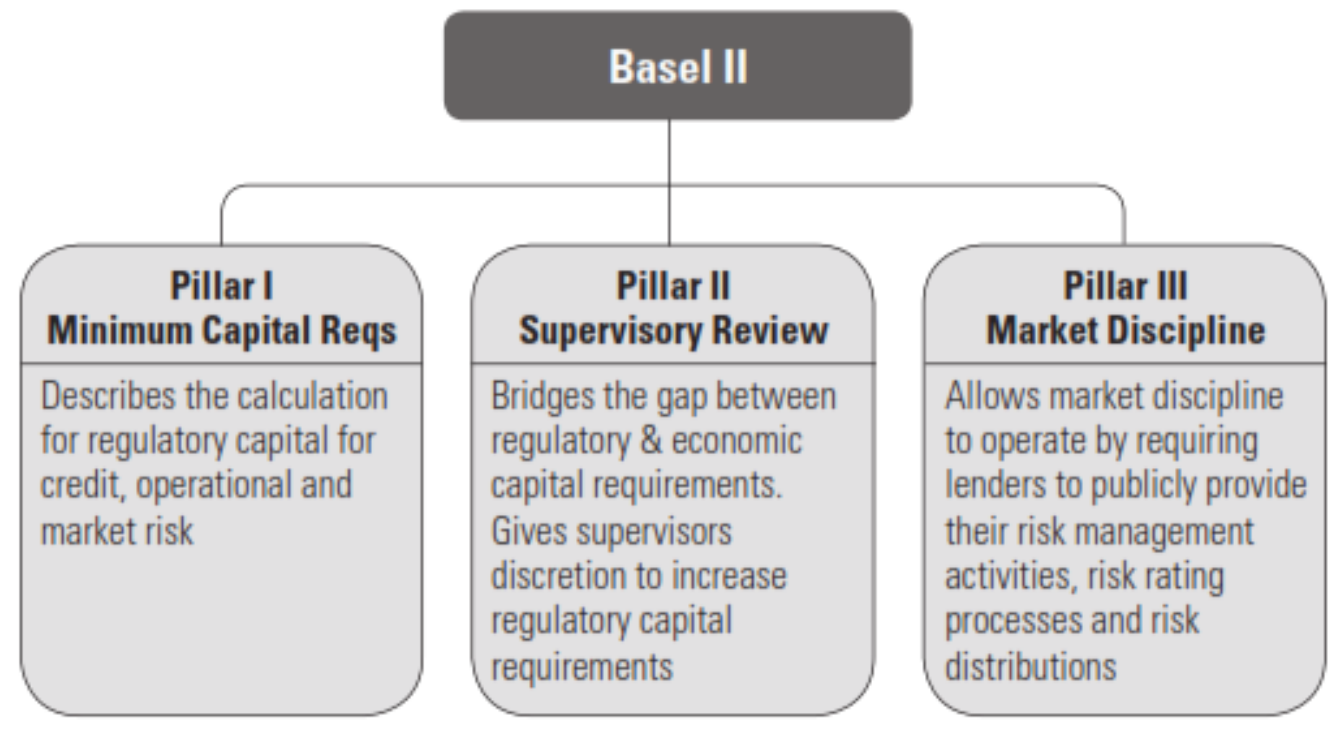

Fig. 1 : The Three Pillars of Basel II Norms

The foundation of Basel II framework is based on three parameters which are mentioned in the discussion of its pillars as follows:

Pillar 1: Minimum Capital Requirement: Banks should maintain a minimum capital adequacy requirement of $8 \%$ of Risk Weighted Assets (RWA) after adjusting their assets for risk.

Pillar 2: Supervisory Review Process: Supervisors will assess and review the risk measurement and risk management system of banks with reference to three types of risks namely operational risk, credit risk and market risk.

Pillar 3: Market Discipline: The third pillar focuses on increasing disclosure requirements of banks. Banks are supposed to compulsory disclose their risk exposure, risk management techniques etc. to central bank. $(4,5)$ 


\section{Benefits of Basel II:-}

- The difference between economic capital and regulatory capital is reduced to a great extent in Basel II because regulatory capital requirement will depend on banks own risk measurement techniques

- Basel II guidelines are better than Basel I considering the fact that Basel II framework is more risk sensitive

\section{Disadvantages of Basel II:-}

- Basel II focuses too much on credit risk

- The calculations of advanced risk approaches is complex and hence difficult for smaller banks and supervisors

- There is a very strong importance attached to the risk profile of assets and hence it can adversely affect the borrowing capacity of small and risky borrowers

- Too much importance is given to credit rating and rating of assets, which makes it difficult for the banks to disburse loans to less rated assets and clients

\section{India's position on Basel II norms:-}

Reserve Bank of India (RBI) issued draft guidelines for implementing a New Capital Adequacy framework in line with Basel II norms. The deadline for implementing Standard Approach of Basel II norms for internationally active domestic banks and foreign banks operating in India is $31^{\text {st }}$ March 2008 whereas the deadline for all other scheduled commercial banks has been extended to $31^{\text {st }}$ March 2009. As per RBI's 2007 guidelines, banks have to calculate their capital requirement in a similar way for Basel I and Basel II standardized approaches, atleast till 2010, so that a minimum floor level is maintained, after which Basel I approach will be phased out.

A steering committee was formed by RBI which consisted of senior managers from 14 banks (including public, private and foreign) with representative members from Indian Banks Association (IBA) and RBI. This committee was further categorized into sub-groups to address particular issues of implementing Basel II norms by banks in India. The same working group prepared guidelines on implementation of the new Basel II Accord, which was sent to all banks in India.

In the beginning, Standardized Approach will be implemented by banks for measuring credit risk and Basic Indicator Approach will be used to calculate operational risk. Some banks will be allowed to shift to Internal Rating Based (IRB) Approach after satisfactory skills are acquired and practiced by the banks and supervisor both.

\section{How will Basel II Norms change Banking in India?}

Basel II norms will change banking in India with reference to benefits received from its implementation, opportunities that can be tapped and improving risk management system across all banks.

\section{Benefits from implementation of Basel II norms in India:-}

Basel II would bring about a change in the way banks do their operations on a daily basis. It would help Indian banks to adopt better risk management practices. This will result in two benefits: one the profits will increase due to improved risk supervision and second the banks will be more competitive with respect to opening up of foreign banks in 2009. It is also expected that Basel II would change the way credit is disbursed by banks leading to change in the lending structure due to credit risk approaches.

\section{Benefit to larger banks:-}

Basel II implementation would benefit larger banks more as they have bigger \& better infrastructure and other facilities for adhering to better risk management approaches. They can also implement various advanced level approaches prescribed by Basel II norms.

\section{Opportunities post Basel II norms:-}

\section{Opportunity to reduce regulatory charge from Basel I to Basel II Standardized Approach:-}

Basel II gives the freedom to national regulators to decide on risk weights of credit exposures of banks. There is an opportunity to decrease regulatory capital charges and save on funding costs which might encourage banks to carry out portfolio adjustments such as lending to rated but strong corporate or increasing their retail lending (with margins greater than $25 \%$ ).

Other opportunities in the Banking Sector:-

Rural India is still under-penetrated as far as banking facilities are concerned. Hence, banks can use this potential market to provide a variety of products and services to rural customers. Banks can increase lending to rural market by way of financing for agriculture loans, micro finance and loans to Self-help groups (SHGs). 


\section{Improving Risk Management Systems in India:-}

As per the directives of Reserve Bank of India, initially Standardized Approach and Basic Indicator Approach will be implemented by Banks in India to mitigate credit risk. Banks are allowed to shift to Internal Rating Based Approach after sufficient skills are acquired at the bank and supervisory level. Banks have been instructed to formulate and operate the Capital Adequacy Assessment Process (CAAP) as required under Pillar II of the Basel II Accord. Implementing Basel II norms will require more capital for banks in the beginning; because operational risk and capital charge for market risk was not recommended under Basel I norms. Nevertheless, this process will assist banks to estimate, measure and manage risks in an improved manner.

\section{Challenges for the Indian banks in implementation of Basel II norms:-}

Indian Banking System consists of Public Sector Banks, Private Sector Banks, Foreign Banks, Co-operative Banks and Regional Rural Banks. The regulatory standards for all these banks are uniform. Indian Banks are still behind in terms of well-organized infrastructure and strong credit rating systems, which act as challenges for Basel II implementation. This might lead to problems in terms of implementation of Basel norms, resulting in foreign banks and larger domestic banks have an edge over other majority banks in India. The implementation of Basel II norms has following important concerns/ apprehensions i.e. the challenges faced by banks in India are broadly classified as follows:

\section{Additional Capital Requirements:-}

Minimum Capital Requirement as per Basel II norms is set at $8 \%$ for credit risk. Even though capital required for credit risk is reduced in Basel II, it will not decrease in real terms due to adoption of more sophisticated risk sensitive approaches.

Also, the capital requirement of banks is likely to increase as Basel II norms have introduced additional capital charge to be maintained for operational risks as a part of greater risk sensitivity. This resulted in many banks keeping aside $20 \%$ or more of their internal capital for operational risk. Some of the banks may not be in a position to comply with this new (additional capital) regulatory requirement.

\section{Data Collection and Credit Assessment:-}

The advanced risk measurement approaches to calculate credit risk, as stipulated by Basel II norms require a 5-year data to calculate credit risk parameters such as Probability of Default (PD), Loss given Default (LGD) and Exposure at Default (EAD). In India, such data sets are partly available, leading to a big challenge in implementing it. Banks are in the process of working out a data pooling arrangement by forming a syndicate.

It also focuses on using Internal Ratings Based method. Most of these models require minimum 5 years bank data which is a tedious and high cost process as most Indian banks do not have such a database.

\section{Cost and Complexity Involved:-}

Public sector banks in India are still a step behind Private sector banks and foreign banks in terms of standardization and better infrastructure facilities all across its branches. Some of the public sector banks also lack in providing core banking services to its customers. Implementation of Basel II norms requires updated high-tech infrastructure facilities for risk measurement and risk management. These approaches will require significant amount of expenditure, which may decrease the profitability of smaller banks. Furthermore, Basel II is said to be complex in terms of interpretation and so its implementation is difficult.

The Basel II Accord incurs high external costs and compliance cost. The supervisors and auditors too will carry heavy cost of ongoing supervisory review process and evaluating bank's internal risk management system and credit risk models. (9)

\section{Choice of Alternative Approaches:-}

Basel II framework offers alternative approaches for calculation of minimum capital requirement to be maintained for measuring various types of risks. But benefits arising from adopting Internal Ratings Based (IRB) approach will result in supremacy of this approach among bigger banks. Large banks implementing IRB approach are more risk sensitive than smaller banks who practice Standardized Approach. This practice will lead to flow of risky assets into banks who adopt Standardized Approach as they will need lower capital for these assets compared to banks who adopt IRB approach. Hence, the smaller banks would retain a lower capital for risky assets than necessary and become more susceptible to risks, so it is low capital but high risk approach. 


\section{Supervisory Framework:-}

Supervisory Skills: There would be huge requirement of skilled staff specialized in risk measurement and risk based supervision to develop and validate complex models to implement Basel II norms. Such staff will be required at both places - supervisory agencies and at the banks. Banks may find it difficult to attract and retain such talented staff for their regular supervisory needs.

\section{Risk Management Architecture/ Infrastructure:-}

The second pillar of Basel II norms require Supervisory Review Process for continuous monitoring of risk measurement and suggest ways for mitigating risk. The third pillar of Basel II norms highlights on Market Discipline, i.e. keep transparency for all bank related activities to its stakeholders. So, here Management of Banks establishes a framework for risk assessment. It is difficult task for the banks to have the risk management architecture which should match with international best practices and required human skills to implement it.

\section{Rating Requirement:-}

The level of rating penetration is very low in India even though there are a few Credit Rating Agencies. Even if the existing rating agencies are considered, it is not possible to cover all the borrowers and get them rated. In addition, credit rating in India is only limited to issues and not issuers. The challenge is to promote rating of issuers in India.

\section{Disclosure Regime:-}

The third Pillar of Basel II norms impose Market Discipline which requires disclosure of important information of bank. Such disclosure ensures transparency and is useful to market participants, supervisors and rating agencies. But too much of revelation may lead to excess of information and may harm the financial position of bank. "It is our experience that poor disclosure not only impinges market discipline but also prevents management making the right decisions. We therefore particularly welcome and support the Committee's moves to reinforce this area of market discipline." (10)

\section{Disadvantage for Smaller Banks:-}

Banks have alternatives to choose from either implementing Standardized Approach or Internal Ratings Based (IRB) Approaches for their minimum capital requirement needs. Small and medium-sized banks will implement Standardized Approach for measuring credit risk which is a simpler model. Other larger banks with major retail business will resort to IRB Approach which has significant capital reduction. Small banks might face the problems of implementing Basel II requirements and setting up of internal credit rating system will be costly for them. However, credit rating system is required to price their loan with respect to other competitor banks. Thus, smaller banks will have high risk assets in its portfolio i.e. high risky loans which might lead to decrease in profits and make them more vulnerable to larger banks.

\section{Problems in Developing Countries:-}

As India is a developing country, it can come across various problems in implementing Basel II norms. The minimum capital requirement as per Basel II Accord will give financial stability or not is a big question to answer. In addition, developing countries have a higher percentage of borrowers with low credit rating. The IRB approach has less significant benefits if banks lend to such low rated borrowers. So, implementing a simpler Standardized Approach will affect the growth of smaller banks in terms of lending and profitability.

\section{External and Internal Auditors:-}

The supervisors may themselves act as internal auditors, but they may need the assistance of external auditors and consultants to carry out some of the responsibilities as per Basel II Accord. The prerequisite is that there should be a suitably developed accounting and auditing standards and framework which matches international standards. Minimum qualifying criteria for firms should be developed who provides such services. They should have trained, appropriate staff, upgraded to meet the needs of banks efficiently and effectively.

\section{Results:-}

The significant findings of the study are summarized into two parts.

Firstly, the implementation of Basel II framework in the Indian Banking System created a few opportunities for banks and thus resulted in several benefits which are discussed herein. 
- The common approach of banks in India with reference to risk management has been changed. There is an improvement in assessing risk, defining risk measuring techniques, finalizing methods to manage risk and gradually eradicating various risks of banks, leading to better financial stability.

- Better risk management leads to decrease in losses and hence improve in the overall profitability of banks.

- Banks can also lower their minimum capital adequacy requirement by adopting advanced IRB Approach as per Basel II guidelines.

- There are several benefits for large banks as they can adhere to banking regulations and practices at international level and manage their risks in a better way compared to smaller banks.

- On the whole, majority banks have become more competitive with reference to their banking operations and managing their obligations to ensure financial stability by following the principles of Basel II Accord.

Secondly, even though there are several benefits of implementing Basel II Accord, Banks in India experienced a few challenges in its process of adopting new framework, which are summarized herein.

- Basel II framework turned out to be a very costly phenomenon in terms of maintaining database for calculation of risks, updating infrastructure requirements, adhering to supervisory needs of bank management, supervisors, internal and external auditors etc.

- The calculation and interpretation of risk measurement approaches as prescribed by the accord is very complex specifically advanced approaches of risk assessment.

- The need of experienced and trained supervisors to play the role of internal and external auditors and continuously review and supervise bank's activities is a serious challenge for banks irrespective of any size.

- There is too much importance to credit rating of assets, which is not feasible in India. The size of borrowers and loans that they need is huge compared to the ones, who can rate them for banks. So, implementing Basel II norms will deprive them of the funds they can borrow.

\section{Conclusion:-}

The basic objective of any bank is to ensure that banking operations are managed efficiently and effectively. The banks in today's scenario are exposed to a variety of risks and a strong regulatory framework can be of great help to withstand the difficulties that might be experienced in performing its activities. One such strong and commendable framework is Basel II Accord which ensures improved risk management system and financial stability to banks. As every coin has two sides, Basel II norms too have been criticized on the grounds of being costly, complex in interpretation, unfeasible in supervision and exaggeration to credit rating agencies. Nevertheless, there are some significant advantages of Basel II accord which has resulted in remarkable growth of banks in India in the areas of improving risk management system of banks, increase in profits and overall being more competitive with reference to international banks. Now banks in India are adopting best banking practices at par with international standards. So, even if there are some challenges in implementing Basel II framework by the banks in India, the opportunities and benefits resulted from it has outweighed all the other difficulties.

\section{References:-}

1. Kawaldeep Kaur, et al., (2014) Banking Industry: Indian Scenario, International Journal of Business Management, Vol. 1(1), pages 8-16

2. (http://www.bis.org/)

3. Rajkumar S Adukia, An Overview of Banking Sector in India, published online at (www.caaa.in)

4. Aditya Srivastava, (2015), Basel Norms explained in simple language, accessed on $23^{\text {rd }}$ April 2015, (http://www.bankexamstoday.com/2015/04/basel-norms-explained-in-easy language.html)

5. Banking Awareness - BIS and Basel Norms, (2015) accessed on $15^{\text {th }}$ January 2015 (http://www.bankersadda.com/2015/01/banking-awareness-bis-basel-norms.html)

6. A to Z of Basel Norms, (2015), (http://competitionzenith.blogspot.in/2015/02/a-to-z-of-basel-norms.html)

7. Leeladhar, V. (2005), "Regulation and Risk Management: Implementing Basel II", RBI Bulletin, August.

8. Chakraborty, Rajesh (2006), "The Financial Sector in India: Emerging Issues", P. 156, Oxford University Press.

9. Basanta Kalita, (2008), Post 1991 Banking Sector Reforms in India: Policies and Impacts, Second Singapore International Conference on Finance, January $31^{\text {st }}$ 2008, available online at SSRN: (http://ssrn.com/abstract=1089020) pages 1-29.

10. Carauna, J., (2003), Basel II: The Road Ahead, Journal of financial regulation and compliance, vol. 11(4), pg 22. 
11. Linnell, I., (2001), A critical review of the new capital adequacy framework, Basel Committee on Banking Supervision and its implications for the rating agency industry, Journal of Banking and Finance Vol. 25, pp. 187-196.

12. Bakshi, S., (2004), Basel Norms: Challenges in India, ICAI publications, CA journal, October 2004 issue (http://www.icai.org/icairoot/publications/complimentary/cajournal_oct04/p426-432-oct04.pdf)

13. Basel II - A Challenge and an opportunity to Indian Banking: Are we ready for it? (www.ficci.com/surveys/II.pdf)

14. Shanu Mittal, (2008), How will Basel II change banking in India?, IIM Lucknow

15. Maria Mathew, (2008), How will Basel II change banking in India?, Loyola Institute of Business Administration, Chennai 